\title{
Copyright Issues on the Prank Video on the Youtube
}

\author{
Nurul Hulwanita Sharfina ${ }^{1}$, Hasbir Paserangi ${ }^{2}$, Fitri Pratiwi Rasyid ${ }^{3}$, Muhammad Ikram Nur Fuady ${ }^{4}$ \\ ${ }_{1,2,3}$ Universitas Hasanuddin, ${ }^{4}$ Universitas Islam Negeri Alauddin Makassar \\ Makassar, Indonesia \\ nurulhulwanitas@gmail.com
}

\begin{abstract}
This study aims to examine copyright infringement that occurs in prank videos uploaded on YouTube social media. The next goal is to find out how the criteria for prank videos that can be said to violate copyright are categorized as cinematographic works. This research was conducted by taking data samples from several cases of viral prank videos in cyberspace and then completing them with the latest data from the Intellectual Property of the Ministry of Law and Human Rights of South Sulawesi Province. Data collection techniques using document studies, interviews, and online surveys. Meanwhile, data analysis was carried out in a qualitative form descriptively and systematically. The results indicate the videos with prank content on Youtube have harmed the parties involved in making these prank videos. The most disadvantaged party is the prank target, both morally and economically, exacerbated by regulations that have not provided optimal legal protection. The regulations in relation are Law Number 28 of 2014 concerning Copyright, Law Number 32 of 2002 concerning Broadcasting, and Law Number 33 of 2009 concerning Film. Furthermore, many YouTubers do not fulfill related rights, namely the moral rights of parties in video content, while the fulfillment of these rights has been regulated in the Copyright Law. Therefore, the responsibility of the relevant parties, namely Youtubers and the Government represented by the Intellectual Property Officer of the Ministry of Law and Human Rights, is essential to do synergy in preventing copyright infringement.
\end{abstract}

Keywords- Copyrights, Prank Videos, Youtube, Youtuber.

\section{INTRODUCTION}

The development of information technology that occurs in today's society is unavoidable. Information technology is one of the most critical needs for humans [1]. Many changes have occurred in meeting people's needs, which were initially analog to digital. This can be seen in today's modern era, where information technology has become a trend of technological development [2]. Information technology is a field of science that is developing and has a considerable influence on the development of human civilization. Technology can be used for discussion, simulation, and learning activities.

Along with the rapid development of information and communication technology, communication can now be done using electronic media, which can connect us with other people outside areas that are not reachable because of the great distance [3].

During the rapid development of digital technology, now almost all needs can be met online. The existence of an internet network also facilitates the flow of information, making it easier for everyone to access what was previously unknown [1]. Everyone around the world can be connected through this facility without moving from one place to another. Everyone can more easily communicate, send or provide information, even channel their aspirations or creativity [4]. Technology has many functions that make it much easier for people to carry out various activities, such as finding work online and earning more accessible economic income.

The presence of technology in the era of the Industrial Revolution 4.0. now, people can also more easily meet their entertainment needs, for example, watching movies [5]. Sophisticated technology makes it easy to access entertainment by watching movies at home via television or smartphones. This can be seen from the various television channels that now have broadcast rights to present quality films. Watching movies can also be done online via the internet using applications that provide movie streaming services such as Netflix, iflix, HOOQ, Netflix, Amazon Prime Video, Catchplay, Viu, and Youtube[6]. People no longer need to go to the cinema to enjoy movies because the entertainment can now be accessed anytime and anywhere, as long as they have adequate devices and are connected to the internet. However, the internet contributes to the improvement of human welfare, progress, and civilization, also has a negative impact. One of the negative impacts that can be caused is copyright infringement, such as using the work without the copyright holder's permission, plagiarism or plagiarism, and alteration of work either in part or in whole [7].

Copyright is one part of intellectual property with the broadest scope of protected objects because it includes science, art, and literature (art and literary), including computer programs [6]. Copyright is a special right for creators or rights holders to publish or reproduce their creations or to give permission for them in the fields of knowledge, art, and literature, with certain restrictions [8]. The creator or copyright holder has moral and economic rights; if one or both of these rights are violated by another party, the creator can claim his rights through litigation or non-litigation.

Article 1, Section 1 of Law Number 28 of 2014 concerning Copyright (from now on referred to as the Copyright Law) stipulates that Copyright is the exclusive right of the creator that arises automatically based on declarative principles after work is realized in a tangible form without reducing restrictions by the provisions of the law invitation [9]. With the declarative principle of copyright, many people do not realize that a work produced can be protected so that it cannot be misused by other 
parties by applicable laws and regulations even though the work is not registered.

Based on Article 28C, Section (1) of the 1945 Constitution of the Republic of Indonesia, it is regulated that everyone has the right to develop themselves and improve their quality of life. Copyright protects so that the creator can fully benefit from the results of his creation. In the Copyright Law, every work of creation is explicitly protected so that every creator can enjoy the benefits of his rights to the work created. In addition, copyright violations will be sanctioned for perpetrators, thus indirectly motivating everyone to work better because of legal guarantees. This law also generally regulates the scope of copyright, validity period, registration of works, licenses, copyright board, related rights, copyright management, fees, dispute resolution, provisional determination of court investigation of criminal provisions, transitional provisions, and closing provisions [4].

Efforts to protect creators of works are also carried out by providing social restrictions not to use, duplicate, distribute, transmit, or publish and other similar activities to a copyrighted work without the consent of the creator or copyright holder or before the protection period expires. The creator is also entitled to compensation for the copyright infringement activities [10].

The enactment of the Copyright Law aims to protect various human creations, one of which is cinematographic works as regulated in Article 40 paragraph (1) letter $\mathrm{m}$ of the Copyright Law. Protected works include works in the fields of science, art, and literature, consisting of 20 kinds that covered in Article 20, Law Number 28 Year 2014 concerning Copyright.

The Copyright Law explains the definition of cinematography, a creation in the form of moving images, including documentary films, advertising films, reports or story films made with scenarios, and cartoon films. Cinematographic works can be done on celluloid tape, videotape, video disc, optical disc, and other media shown in the cinema, widescreen, television, or other media. Cinematography is an example of an audiovisual form such as film [11].

The film is a work of art and culture, which is a social institution and mass communication media made based on cinematographic rules with or without sound and can be shown [12]. The film is known as a storage medium for these cinematographic works. Films are produced by recordings of people and things with a camera and by animation.

Based on Article 1 section (1) of Law Number 33 of 2009 concerning Film [12]. The film is defined as various things related to the film. The film is defined as a work of art and culture, a social institution, and mass communication media made based on cinematographic rules with or without sound and can be shown.

Based on this definition, the current film industry is very close to the community, and a video is uploaded via Youtube social media. Youtube is a social media that is now much favored by the public because it provides the freedom to upload videos or moving images with varied content [13]. Based on the elements described in the film, it can be said that the video uploaded on the YouTube social media is a cinematographic work. Therefore, all forms of art, which are social institutions and mass communication media with sound or without sound and can be displayed, are included as objects protected by the Copyright Law.

Youtube is a video site that provides various information in the form of "moving images." This application is provided for those who want to search for video information and watch it live. Everyone can participate in uploading videos to social media Youtube and share them worldwide in an unlimited number of ways. Youtube is here as a place for users to upload and share their recording experience with others [14].

The freedom to upload videos to Youtube makes everyone have different desires, both for economic benefits or just for entertainment. Individuals or each person who has a Youtube account and diligently uploads videos with various content to his account, familiarly called Youtuber [14]. Today, video content is often used by Youtubers, one of which is making prank videos or jokes that aim to prank others [15].

Prank videos are made mainly by Youtubers and often harm people involved in videos usually uploaded on Youtube social media. One of the harmful prank videos is the video of online motorcycle taxis being asked to buy food orders of up to millions of rupiah, but the customer suddenly cancels the order unilaterally. This incident was included in the Youtuber's video content and went viral. This can be seen as a form of disgraceful act showing fraudulent acts of ordering online motorcycle taxis, coupled with the uploading of the video without the permission of the online motorcycle taxi driver, which is contrary to the Copyright Act [16]. In addition, there are also prank videos that pretend to be dead to prank friends, relatives, or family until they are shocked and faint [17]. In addition, there are still many examples of prank videos that are rife in today's society and seem to have become commonplace to do.

Based on these facts, the prank videos that are freely uploaded by Youtubers are cinematographic works protected by the Copyright Law, and Youtubers, as creators, can benefit from their work. However, on the other hand, the uploaded prank videos sometimes contain disgraceful acts that are not worthy of being shown to the general public.

This is compounded by the absence of protection of the rights of the person who is the object of the content in the video. Many victims feel that their reputations have been tarnished due to videos circulating on YouTube social media, which were carried out without the permission of the individual who is the object of the video content.

Youtube social media has created protection in "Policy and Security," which prohibits the public from uploading videos to Youtube with content that harms others and violates the Copyright Act [18]. Many prank videos violate copyright and harm the public for fear of becoming viral on social media. Therefore, legal protection is needed for Youtubers in creating creations while protecting the rights of others who are the content in the prank video. 
Researchers look at legal issues regarding potential copyright infringement on prank videos which are cinematographic works through the use of the Youtube social media application with a focus on:

1. How is copyright protection against prank videos uploaded on Youtube social media?

2. What are the roles and responsibilities of Youtuber and the Indonesian government towards prank videos that violate the laws and regulations in Indonesia?

\section{RESEARCH METHOD}

The research is a qualitative by the empiricil and statue approach [19]. Researchers extracted data by taking the primer data in the field then described it by the existence regulation [20].

The research location is in the Intellectual Property Sub-District Office of the Ministry of Law and Human Rights of South Sulawesi and Youtube, considering that these agencies are related to the problem to be researched Youtubers.

The population of this research is prank videos uploaded by Indonesian Youtubers to Youtube social media, which can violate the Copyright Law and cause harm to others. Then, the sample in this study is a video uploaded by Indonesian Youtubers in the community that can violate the Copyright Law.

In conducting the research, the researcher used the following data collection techniques by the interview to collect data directly through question and answer based on a list of questions prepared to obtain the necessary data and information [21]. In this study, a direct search was conducted by interviewing parties related to the problems to be studied in this study, such as Youtubers that uploaded the content in Youtube and the officer of Copyrights protection officer under the Ministry of Law and Human Right, Republic of Indonesia.

The rest of data also taken by do some online survey trough google survey to the public and the Yotubers to obtain their perspectives regarding the violence on prank videos [22].

\section{FINDINGS AND DISCUSSION}

The results of Prank videos on Youtube are explained as follows.

\section{Copyright Protection Against Prank Videos Uploaded on Youtube Social Media}

As previously explained, the prank is an act of ignorance; then, the act is manifested in a video that often harms other people. Based on this, a prank video can be interpreted as a video made by a person or group to prank others and allow users to upload it on the Youtube social media application. The prank videos in question are videos that cause harm and videos that are uploaded without the victim's knowledge, causing copyright infringement in the video.

Furthermore, in this study, researchers divided prank videos into two types, namely prank videos that were made that had obtained permission from the parties and videos that did not get permission from the parties. Permission from the parties in question is the parties involved in the video, such as the video maker or Youtuber and other people in the video. People other than Youtubers are often victims in these videos.

In addition, researchers found similarities in the two types of prank videos, where both types of videos have been planned through scenarios or settings between the Youtuber and the other party who suffered losses. Prank videos that are made without good planning, where the video maker aims to prank others without the victim's knowledge so that his actions cause harm to the victim and the public who watch videos that have been uploaded on Youtube social media.

Prank videos as one of the cinematographic works have been regulated in Law Number 28 of 2014 concerning Copyright. Cinematography works, better known as film, are audio-visual art that arises from a person's thinking or intellect [23]. The ideas that arise are then developed, produced, and finally produce a real work that everyone can enjoy as stipulated in Article 40 paragraph (1) letter m of the Copyright Law.

The Copyright Law explains the definition of cinematography, a creation in the form of moving images, including documentary films, advertising films, reports or story films made with scenarios, and cartoon films. Cinematographic works can be done on celluloid tape, videotape, video disc, optical disc, and other media shown in the cinema, widescreen, television, or other media. Cinematography is an example of an audiovisual form such as film [23]. Article 40 of Law Number 28 of 2014 is an article that clearly shows that cinematographic works are protected works that fall into the category of works in the field of science. This is explained in the letter $(\mathrm{m})$.

Looking at this definition, several laws and regulations regulate it, namely as follows.

\section{a. Protection in the Perspective of Law Number 28 of 2014 concerning Copyright.}

Law Number 28 of 2014 concerning Copyright is a legal product that regulates the copyright of work and how to protect a work created. Article 1 paragraph 1 stipulates that [9]:

Copyright is the creator's exclusive right that arises automatically based on declarative principles after work is realized in a tangible form without reducing restrictions by the provisions of laws and regulations.

In his book, H. OK. Saidin provides a comparison of the notion of copyright [24]. First, under Article 1 in Auteurswet 1912, copyright is the sole right of the creator, or the right of the person who has the right, to his creations in the fields of literature, knowledge, and art, to publish and reproduce them, taking into account the limitations imposed by the law. Constitution [25].

Second, based on the Universal Copyright Convention. In Article $\mathrm{V}$ of the Universal Copyright Convention, it is regulated that [25]: 


\begin{abstract}
"Copyright includes the sole right of the author to create, publish and authorize the translation of the work protected by this agreement."
\end{abstract}

If one examines the limitations of understanding given by the two provisions above, it can almost be concluded that both provide the same meaning, namely that copyright is a special right or exclusive right owned by the creator. Further explanation regarding the term exclusive rights of the creator is that no other party may take advantage of these rights except with the author's permission.

Furthermore, the basic idea of the copyright system is to protect the original form of human creations born because of their intellectual abilities. This legal protection only applies to creations that have been in a distinctive form so that they can be seen, heard, or read if you look at the explanation of copyright, in this case, a prank video on Youtube social media, which is a web feature that provides various kinds of videos which are certainly a cinematographic work.

Article 40 Paragraph (1) of the Copyright Law explains protected copyrighted works, which fulfills this explanation that the elements in a cinematographic work are the same as the elements in making prank videos so that it can be said that prank videos are cinematographic works. In its development, prank videos uploaded on Youtube social media vary widely, ranging from mere entertainment to obtaining economic benefits by making videos that harm others so that many Youtube users watch them.

Article 3 letter b of the Copyright Law regulates copyright and related rights. Copyright has been clearly explained previously; then related rights are exclusive rights owned by creators, including performers' moral rights and economic rights as regulated in Article 20 of the Copyright Law.

They are making prank videos uploaded on Youtube often does not fulfill the moral rights of the performers or the people involved in the videos, such as prank targets and other actors.

Based on these facts, the researcher argues that:

1) Prank videos uploaded on Youtube do not fulfill the related rights, namely the performers' rights, wherein in this case, the prank target feels materially and immaterially harmed is a violation of the provisions of Article 20 of the Copyright Act. As a result, creators of prank video content are not entitled to copyright protection.

2) The definition of cinematographic works in the Copyright Law contradicts the notion of copyright itself, including prank videos. Normatively, prank videos are cinematographic works that must be protected as stipulated in Article 40 of the Copyright Act. However, on the other hand, there are prank videos that harm other people who violate applicable regulations.

The researcher's opinion is supported by data from interviews with Johan Komala Siswoyo, SH, an official of the Sub Division of Intellectual Property Services, the Regional Office of the Ministry of Law and Human Rights of South Sulawesi specifically stated that prank videos were deliberately made to harm other people and cause harm and were uploaded. The copyright has been violated; the video uploaded on Youtube social media cannot be protected by the Copyright Act [26]. He added that, if you look at the definition of copyright in Article 1 Paragraph (1) of Law Number 28 of 2014 concerning Copyright, a work created must meet the provisions of the law, even if it is a video uploaded without the knowledge of the parties. If pranked, then it has been violated, and it is better if all works made must be with permission so that the moral rights in the copyrighted work are not disturbed [26].

\section{b. Protection in the Perspective of Law Number 33 of} 2009 concerning Film.

The aspect of protection against prank videos uploaded on Youtube can also be seen from the perspective of Law Number 33 of 2009 concerning Film. Article 1 Paragraph (1) of Law Number 33 of 2009 concerning Film stipulates that [12]:

The film is a work of art and culture, a social institution, and mass communication media based on cinematographic rules with or without sound and can be shown.

In connection with the provisions in the article above, prank videos uploaded on Youtube social media can be categorized as works made based on cinematographic rules or short films. Prank videos are in electronic data because some sounds and images can be shown through social media Youtube. This is reinforced by the opinion of Johan Komala Siswoyo, who explained that prank videos watched from social media Youtube, which were categorized as cinematographic works, were simplified by him with the word content [26].

Based on the elaboration of the research results above, it can be seen that videos uploaded to Youtube social media are rigorous. Youtube insists that making videos and uploading must be carried out based on the policies and security that have been made.

The application of Youtube's policies and security is also the same as the application of the provisions for the protection of prank videos which are cinematographic works protected as copyright. It is also the same with prank videos as short films protected by the Film Act.

c. Protection in the Perspective of Law Number 32 of 2002 concerning Broadcasting.

Law Number 32 of 2002 concerning Broadcasting does not regulate broadcasting services based on social media applications. According to researchers, videos on Youtube social media are broadcast content, so they need to be regulated in the Law on Broadcasting. The definition of broadcasting and broadcasting has been regulated in Article 1 Paragraph (1) and Paragraph (2), stipulating that [27]:

1) Broadcast is a message or series of messages in the form of sound, images, or sound and images or graphics, characters, whether interactive or not, which can be received through broadcast receiving devices. 
2) Broadcasting is the activity of transmitting broadcasts through broadcasting facilities and transmission facilities on land, at sea, or in space by using a radio frequency spectrum through the air, cable, and other media to be received simultaneously and simultaneously by the public with a receiving device. Broadcast.

This is by the opinion of Prof. Judhariksawan, who is the former chairman of the Indonesian Broadcasting Commission (KPI) that it was explicitly stated that Youtube broadcasts are more accurately said to display broadcasts instead of broadcasting broadcasts because broadcasting activities are carried out not on television and radio but social media [28].

According to the researcher, Article 1, Section (1) and (2) of the Law on Broadcasting also include prank videos on Youtube social media because Youtube videos are broadcast objects broadcast through social media. Meanwhile, looking at the definition of broadcasting, broadcasting through Youtube social media cannot entirely be regarded as broadcasting because broadcasting activities can be received simultaneously by the public with broadcast receiving devices. The public does not simultaneously receive broadcasts via Youtube social media unless Youtube users follow Youtuber accounts (subscribe).

Law Number 32 of 2002 concerning Broadcasting also regulates broadcast media in Indonesia. This is regulated in Article 13 Paragraph (1), which stipulates that broadcasting services consist of: radio broadcasting and television broadcasting services [27].

Based on Article 13 Paragraph (1), the regulated broadcast media is only through radio and television. Radio broadcasting is a hearing mass communication medium that distributes information in the form of sound, and television broadcasting is a visual and auditory mass communication medium that distributes information in sound and images [27].

According to the researcher, the provisions in Law Number 32 of 2002 concerning Broadcasting are insufficient to protect the public. This legal product needs to be updated by including broadcasting content through social media both nationally and internationally, such as Google and Youtube, as broadcasting services to be filtered beforehand. The election in question is an activity to filter content that is not suitable for public consumption, ranging from pornography, racial intolerance, and hoaxes that will harm the community.

2. The roles and responsibilities of Youtube, Youtubers, and the Government for prank videos that violate the laws and regulations in Indonesia

After knowing the laws and regulations relating to prank videos as copyrighted works that must be protected through the copyright law, the film law, and the broadcasting law, the next thing that needs to be discussed is the role and responsibility of the parties involved. Related parties. The roles and responsibilities of these parties will be explained as follows. a. The Role and Responsibilities of Youtubers or Content Creators Against Copyright Violations in Prank Videos

Individuals or everyone who has a Youtube account and diligently uploads videos with various content to their accounts, familiarly called Youtubers or can also be called content creators. However, not all Youtube users can be Youtubers because most people have a hobby of uploading videos regularly and content. Currently, video content is often used by Youtubers, one of which is making prank videos or jokes that aim to prank others.

Youtuber as a content creator can be called the creator of the prank videos he makes. Therefore, a Youtuber should know the applicable regulations, both government regulations, and Youtube regulations.

Of the many Youtubers in Indonesia, only a small number have ever made prank video content. Various public responses can be seen on social media regarding prank video content on Youtube, ranging from positive to negative responses.

Researchers have surveyed to find out what people think about prank video content on Youtube. The survey was conducted on 96 online public responses via google form from March 20, 2020, to June 20, 2020. The classification of respondents to the online survey is in table 1 below.

\section{TABLE 1. ONLINE COMMUNITY SURVEY RESPONDENTS}

\begin{tabular}{|c|c|}
\hline AGE (YEAR) & AMOUNT (PERSON) \\
\hline $13-17$ & 25 \\
\hline $18-25$ & 25 \\
\hline $26-40$ & 25 \\
\hline $41-60$ & 21 \\
\hline
\end{tabular}

The respondent's data has represented each age category. Next, the researcher presents community survey data about whether Youtubers need to ask permission from the parties involved in the video content before uploading, as shown in the diagram below.

Public Opinion about Prank Videos in Youtube
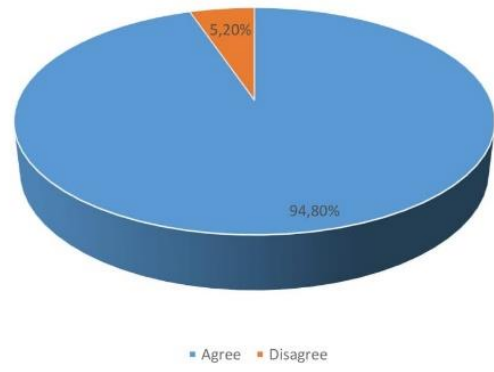

Fig.1 Diagram of public opinion data regarding permission requests to people involved in prank videos

Based on diagram 1, we can see the comparison ratio of people's perspectives on the request for permission of the 
parties involved in the prank video content. The study results show that most people want Youtubers to ask permission from parties involved in prank video content, especially prank targets. This is in line with Article 20 of the Copyright Law on Related Rights, which explains that creators of works, Youtubers, are obliged to fulfill four related rights, especially moral rights.

Many Youtubers violate moral rights, namely rights attached to Performers (prank targets) that cannot be removed or cannot be removed for any reason even though their economic rights have been transferred. So many prank video content on Youtube are created and uploaded without the knowledge of the prank target. When the video has been uploaded, people will be surprised and not happy about it.

This is exacerbated by the motivation of Youtubers who pursue popularity and economic gain for themselves by not telling prank targets about video content uploaded on Youtube. As a result, various fights or squabbles on Youtube social media, for example, the complaint of the mother of the pocong prank victim in Jakarta who reported it to the local police [29].

As a prank video creator, Youtuber is entitled to exclusive rights that must fulfill the related rights involved in the video. When there is a violation in the prank video content, Youtubers must be prepared to face the legal consequences.

Based on the results of online community surveys, people generally agree that prank videos get copyright protection. Here are the data about it.

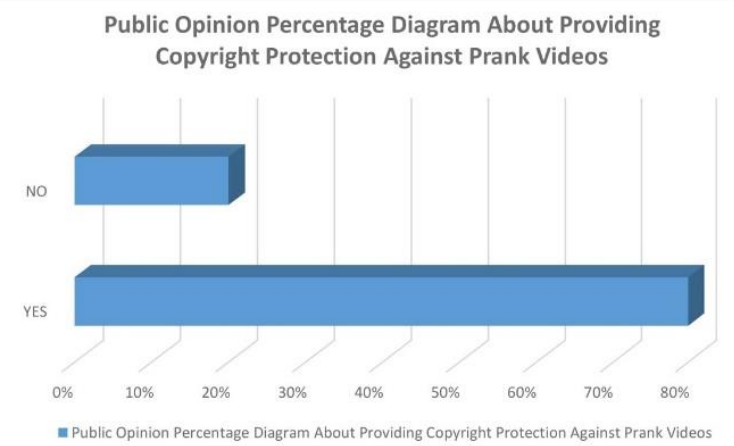

Fig. 2. Public Opinion Percentage Diagram about Providing Copyright Protection Against Prank Videos

The data above shows that most people agree to provide copyright protection for prank videos. As many as $81.2 \%$ of community respondents agree with the condition that Youtubers fulfill the moral rights of those involved in prank video content, especially prank targets. There will be violations and losses for the prank target if the prank video content is widely circulated without the prank target's knowledge. In addition, $19.8 \%$ of respondents do not agree with copyright protection for prank videos because prank videos are not helpful and only harm the community.

Based on these results, the researcher agrees with the public's opinion that wants protection against prank video content on Youtube. However, this can apply with several conditions, namely the fulfillment of related rights, especially moral rights. This is because related parties also have rights to the circulation of the video, such as ensuring the good name of the prank target in the video.

Therefore, the researcher recommends regulating cinematography that regulates which types of cinematography deserve protection and do not get copyright protection. In this case, it also needs to be emphasized about prank video content or the like that fulfills the element of copyright protection, such as the fulfillment of related rights by the creator.

\section{b. Government Efforts and Law Enforcement}

Furthermore, efforts to protect and account for copyright carried out by the Directorate General of Intellectual Property Rights and Sub Intellectual Property Rights can be categorized into two types, namely:

1) Preventive Effort

a) Socialization

One of the preventive or preventive efforts carried out by the Directorate General of IP and Sub KI is socialization. Socialization is a movement to go directly to the field, such as the campus community and the community in the village. This is by the results of interviews with the South Sulawesi Kemenkumham SubKI party, who have carried out socialization such as public lectures, talk shows, scientific discussions, and seminars at schools and campuses.

\section{b) Education}

Education is an activity of transforming knowledge to the public through online and offline platforms. Examples of educational activities that have been carried out by the Directorate General of Intellectual Property Rights and Sub KI of the Ministry of Law and Human Rights of South Sulawesi are making and uploading videos on the Youtube channel of the Ministry of Law and Human Rights of the Republic of Indonesia by live streaming or live broadcasts regarding potential IPR violations in the process of handling copyright infringement reports.

2) Repressive Effort

\section{a) Mediation}

Mediation is an effort to handle reports before entering the judicial process. Mediation is carried out between the alleged perpetrator of the violation and the complainant who feels aggrieved. Mediation can be carried out at the South Sulawesi Ministry of Law and Human Rights Office, mediated by the Sub-Directorate General of Intellectual Property Rights. 
b) Criminal Law Process

If the mediation process is unsuccessful, then the party who feels aggrieved can file a criminal lawsuit to the local district court, as shown in the chart on page 81 .

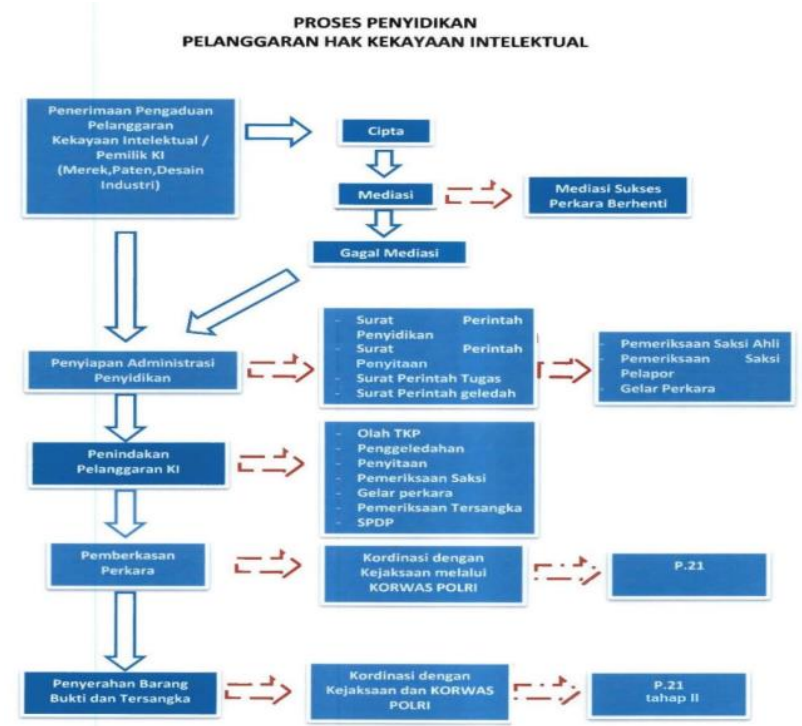

Fig. 3 The process of investigating copyright infringement on intellectual property in Indonesia

The following is the process of investigating copyright infringement on intellectual property in Indonesia. The results of research at the Ministry of law and human rights provides an explanation that, if there is a violation and there is a report from the public, then mediation will be carried out, but if mediation fails, it will proceed to the investigation stage by the prosecutor and police, as shown above.

The Directorate General of Intellectual Property and Sub-IP, as representatives of the Government in protecting copyright, including prank videos uploaded on Youtube, has its procedures when copyright infringement occurs. The researcher directly visited the Kemenkumham Sub KI, South Sulawesi Regional Office, to obtain primary data related to these rights.

Based on the results of an interview with Johan Komala Siswoyo, SH, who is an official of the Intellectual Property Service Sub Division on June 11, 2020, that:

1. There have never been any reports of violations of prank video content on social media, including Youtube social media and the like;

2. Reports on alleged copyright infringement reported to the Sub-KI of the Ministry of Law, and Human Rights of South Sulawesi are only in the form of reports of copyright infringement on songs (music);

3. If there is a violation of Intellectual Property Rights, the Directorate General of Intellectual Property Rights will carry out mediation efforts first. Furthermore, if mediation fails, an investigation will be carried out in collaboration with the police and the prosecutor's office. The following is the procedure for handling reports of IPR violations at the Directorate General of IP.
The solution flow can be seen in the following attachment.

\section{IV.CONCLUSION}

Video content on Youtube social media is a cinematographic work that the Copyright Act protects. However, protection against videos with prank content on Youtube that harm parties involved in video content, such as prank targets, has not been regulated, either according to Law Number 28 of 2014 concerning Copyright, Law Number 32 of 2002 concerning Broadcasting, and Law Number 33 of 2009 concerning Film;

The study results show that there is a violation in the copyright protection of prank video content, where Youtubers as content creators do not fulfill related rights, namely the moral rights of those involved in video content, especially prank targets which have been regulated in the Copyright Act. As a result, many problems occur due to the spread of the video on Youtube, which endangers and harms the good name of the prank target.

The role and responsibility of Youtubers and the Government, in this case, the Directorate General of Intellectual Property (KI) of the Indonesian Ministry of Law and Human Rights, and Sub-KI at the South Sulawesi Ministry of Law and Human Rights Regional Office as related parties, need to be synergized in preventing copyright infringement.

\section{RECOMMENDATION}

In order to make regulations regarding cinematographic works that regulate whether or not the video work can be protected, including prank video content because a lot of prank video content is detrimental to the community. The Directorate General of Intellectual Property of the Ministry of Law and Human Rights of the Republic of Indonesia and Sub KI of the Regional Office of the Ministry of Law and Human Rights of the Republic of Indonesia as the leading sector of copyright protection must be more aggressive in conducting socialization and education, especially to Youtubers in order to avoid copyright infringement.

\section{REFERENCES}

[1] U. Padjadjaran, "The Role Of Critical Information On Self-Induced Competitiveness," J. Akunt. dan Bisnis, vol. 19, no. 1, pp. 43-53, 2019.

[2] A. M. Suherman, Aspek Hukum dalam Teknologi (Legal Aspects in Technology). Jakarta: Ghalia Indonesia, 2002.

[3] F. T. Talika, "Manfaat Internet Sebagai Media Komunikasi Bagi Remaja Di Desa Air Mangga Kecamatan Laiwui Kabupaten Halmahera Selatan (Benefits of the Internet as a Communication Media for Teenagers in Air Mangga Village, Laiwui District, South Halmahera Regency)," J. Media Inf. dan Komun., vol. V, no. 1, pp. 15-30, 2016.

[4] R. A. Rantung, "Hak Cipta Dalam Jaringan Internet Ditinjau Dari Undang-Undang Nomor 19 Tahun 2002 Tentang Hak Cipta (Copyright in the Internet Network Judging from Law Number 19 of 2002 concerning Copyright)," J. Ilmu Huk. Sam Ratulangi, vol. II, no. 1, pp. 30-42, 2014.

[5] L. Koh, G. Orzes, and F. (Jeff) Jia, "The fourth industrial revolution (Industry 4.0): technologies disruption on operations and supply chain management," Int. J. Oper. Prod. Manag., vol. 39, no. 6/7/8, pp. 817-828, Jan. 2019, doi: 10.1108/IJOPM-08-2019-788.

[6] O. P. Ohiagu, "Internet as Medium of the Mass Media," Kiabara J. Humanit., vol. 16, no. 2, pp. 225-232, 2011. 
[7] Y. Nurhayati, I. Ifrani, A. H. Barkatullah, and M. Y. Said, "The Issue of Copyright Infringement in 4.0 Industrial Revolution: Indonesian Case," J. Media Huk., vol. 26, no. 2, pp. 122-130, 2019, doi: 10.18196/jmh.20190128.

[8] M. Fuady, Pengantar Hukum Bisnis (Introduction to Business Law). Bandung: Citra Aditya Bakti, 2011.

[9] R. of Indonesia, Article 1, Section 1, Law No. 28 Year 2014 concerning Copyrights. 2014.

[10]K. Roisah, Konsep Hukum Hak kekayaan Intelektual (Intellectual Property Rights Legal Concept). Malang: Setara Press, 2015.

[11]R. of Indonesia, Article 20, Section 1, Law Number 28 Year 2014 concerning Copyrights.

[12] R. of Indonesia, Law Number 33 Year 2009 concerning Film. 2009.

[13]D. de Jong, "The Advantages and Disadvantages of YouTube," Snob Monkey, 2019. https://snobmonkey.com/the-advantages-anddisadvantages-of-youtube/\#: :text=Gives you the opportunity to earn money through your videos, have a Google AdSense account.

[14]"Pengertian Youtube (Youtube Definition),"Wikipedia.com, 2020. https://id.wikipedia.org/wiki/Youtube.

[15]I. Cahyani, "Pengertian Video Prank (Prank Videos Definition)," berita.com, 2020. https://www.berberita.com/apa-itu-prank-textchat-video-ini-arti- dan-contoh-ngeprank/.

[16]Roy, "YouTuber, Prank Order Fiktif Ojol Itu Jahat \& Tak Manusiawi (YouTuber, Ojol's Fictitious Prank Order Is Evil \& Inhuman)," Cnbcindonesia.com, 2020. .

[17] "Video Prank Pura-Pura Mati (Prank Videos Pretending to be Dead)," Youtube.com 2020. https://www.youtube.com/watch?v=tWEoSFsMIu4

[18] Youtube, "Kebijakan Youtube (Youtube Policy)," Youtube.com, 2020. https://www.youtube.com/intl/id/about/policies/\#communityguidelines

[19]B. Marshall, T. Heinzen, and K. Roberts, Qualitative, Quantitative, and Mixed Methods Research Designs, Fifth Edit. California: SAGE Publications Inc, 2018.

[20]W. L. Neuman, Social Research Methods: Qualitative and Quantitative Approaches, Seventh Ed., vol. 30, no. 3. England: Pearson Custom Library, 2002

[21]M. Knapik, "The Qualitative Research Interview: Participants' Responsive Participation in Knowledge Making," Int. J. Qual Methods, vol. 5, no. 3, pp. 77-93, Sep. 2006, doi: $10.1177 / 160940690600500308$.

[22] V. Braun, V. Clarke, E. Boulton, L. Davey, and C. McEvoy, "The online survey as a qualitative research tool," Int. J. Soc. Res. Methodol., pp. 1-14, Aug. 2020, doi: 10.1080/13645579.2020.1805550

[23] I. A. Hasbir Paserangi, Hak Kekayaan Intelektual. Hukum Hak Cipta Perangkat Lunak Program Komputer dalam hubungannya dengan Prinsip-Prinsip TRIPs di Indonesia (Intellectual property rights. Computer Program Software Copyright Law in relation to the TRIPs Principles in Indonesia). Jakarta, 2011.

[24]H. O. Saidin, Aspek Hukum Hak Kekayaan Intelektual (Legal Aspects of Intellectual Property Rights). Jakarta: PT. Raja Grafindo Persada, 2006.

[25]B. P. H. Nasional, "Seminar Hak Cipta (Copyright Seminar)," 1976.

[26]Johan Komala Siswoyo, "Results of interview with Implementing Officer of the IP Service Sub-Division of the Regional Office of the Ministry of Law and Human Rights, South Sulawesi," Makassar, 2020.

[27]R. of Indonesia, Article 1, Section 1, point 2 on Law Number 32 Year 2002 concerning Broadcasting. 2002

[28]A. M. F. Fahrezha, "Tinjauan Hukum Terhadap Pelanggaran Hak Cipta Pada Pengguna Aplikasi Media sosial Bigo Live (Legal Review Against Copyright Infringement on Bigo Live Social Media Application Users)," Hasanuddin University, 2017.

[29]Z. A. Putri, "Ibu Korban Prank Pocong Erlanggs: Tak Ada Izin Unggah Video! (Mother of Pocong Erlanggs Prank Victim: No Permission to Upload Videos!)," Detiknews.com, 2020. https://news.detik.com/berita/d-3968317/ibu-korban-prank-pocongerlanggs-tak-ada-izin-unggah-video. 